\title{
HOW ENGLISH TEACHERS LEARN IN INDONESIA: TENSION BETWEEN POLICY-DRIVEN AND SELF- DRIVEN PROFESSIONAL DEVELOPMENT ${ }^{1}$
}

\author{
I. G. A. Lokita Purnamika Utami \\ (lokitapurnamika@undiksha.ac.id) \\ Universitas Pendidikan Ganesha \\ Jalan Udayana No. 11, Singaraja 81116, Bali, Indonesia \\ Sarah Prestridge \\ (s.prestridge@griffith.edu.au) \\ Griffith University \\ 176 Messines Ridge Road Mt Gravatt, Queensland 4122, Australia
}

\begin{abstract}
Professional Development (PD) and Professional Learning (PL) are established terms which are used interchangeably but theoretically have notable differences. The former is formally and externally designed while the latter is more informal and self-directed. These differing characteristics have not been observed in the context where PD is normally governed by government policy. As such, there is little to no research on Indonesian English teachers' practice, preferences and dispositions for PD or PL. A qualitative study was conducted involving four English teachers from Indonesia who demonstrated active participation in professional development and professional learning activities. Developmental interviews were the main source of data. The study showed distinct variance in these teachers' preference and action for PL through online networks, self-chosen PD and knowledge-sharing interactions with their colleagues. The study observed compliant dispositions and indifferent dispositions towards school PD policy. The study suggests the need to shift compliancy and policy measures from formal school based professional development to include online professional learning opportunities
\end{abstract}

\footnotetext{
${ }^{1}$ This article is based on a paper presentation at the 65 th TEFLIN International Conference at Universitas Negeri Makassar on 12-14 July 2018
} 
that the teachers initiate, with the integration of both approaches needing further research and development.

Keywords: professional development, online professional learning, English teacher, education policy

DOI: http://dx.doi.org/10.15639/teflinjournal.v29i2/245-265

Teacher quality is significantly influential on students' learning and their achievement (Gore, 2014). To maintain teacher quality and currency, English teachers are expected to improve their knowledge and skills continuously (Cahyono, 2008; Cho, 2014). Engaging in professional development has been mentioned by many studies as a way to improve English teachers' quality by keeping abreast of new knowledge and innovation (see, e.g., Ashadi, 2010; Beltran \& Percy, 2014; Dayoub \& Bashiruddin, 2012).

Current literature suggests that formally structured professional development is increasingly considered as a 'traditional' approach to professional development since teachers are not involved in constructing their learning (McCray, 2016) rather it is assumed that they “...need direct instruction about how to improve their skills and master new strategies" (Lieberman \& Miller, 2014, p. 7). Traditional professional development is characterized by seminars or workshops that are formal and externally structured (Stevenson, Hedberg, O'Sullivan, \& Howe, 2016), are led by invited experts (Trust, Krutka, \& Carpenter, 2016), involve non-participatory types of learning environments (Brooks \& Gibson, 2012) in which teachers are treated as passive receivers who are "deficient and in need of fixing" (Ying, 2012, p. 176). This is why traditional professional development fails to be effective (Trust, et al, 2016). Teachers are 'forced' to attend school-based professional development, or 'required' professional development (Evans, 2011), and it is very often not related to their needs but rather related to school based agendas (Ashadi, 2010; Evans, Tate, Navarro, \& Nicolls, 2009; Opfer \& Pedder, 2011). In fact, scholars have found teachers' lack of enactment (Kennedy, 2016) of knowledge gained in professional development, which means attending professional development does not impact their actual teaching practices (Cho, 2014).

The term 'development' implies a 'passive sense' (O'Brien \& Jones, 2014, p. 683) in that "the process is doing to and for teachers rather than with them" (Nilsson, 2012, p. 238). Alternatively, some scholars critique such an assump- 
tion that professional development is 'done' to teachers because the validity of professional development should be evident in its capacity to equip teachers to act as shapers, promoters and well-informed critiques of reform (Little, 1999). Furthermore, professional development is associated with systematic 'professional' career progression, while 'development' in education is not so linear, so a term which implies a degree of flexibility is required (O'Brien \& Jones, 2014). Scholars have recently distinguished the term professional learning from traditional professional development as it has "broader, more critically reflective and less performative approach" (O'Brien \& Jones, 2014, p. 684) and is informal and self-directed (Loughran, 2010; Nilsson, 2012; O'Brien \& Jones, 2014, Stevenson, et al., 2016). The ideology behind the concept of professional development and professional learning is different and "that difference matters" (Nilsson, 2012, p. 238).

This distinction among the two terms is more profound with the proliferation of technology advancement. The world wide web has expanded options for learning for teachers beyond attending required or demanded school based professional development. Teachers have greater alternatives for learning because now learning can also take place online at anytime (Aubusson, Schuck \& Burden, 2009; Hsiao, Brouns, Kester, \& Sloep, 2013; Loughran, 2010; Stevenson, et al., 2016). Carpenter and Krutka (2014) suggest that online professional learning combats isolation associated with content areas, philosophical, methodological and professional roles. Teachers can learn online from the work of others, seek curriculum resources as well as methods of practice which have been applied by others.

Professional learning through online networks allow teachers to learn without the restriction of certain school agenda (Day \& Sachs, 2004), based on their self-interest or needs (Ambler, 2016) and to learn through goal-directed activities (Raphael, Vasquez, Fortune, Gavelek \& Au, 2014). Online professional learning allows teachers to have a more active role (Easton, 2008) as English pedagogical experts who constantly try to solve problems and improve practice. Teachers can personalize their learning by combining various site (school) based learning with what they are learning online (Beltran \& Peercy, 2014; Campana, 2014).

Conceptualization of online professional learning has been given little attention, especially in the context where traditional professional development strongly influences teachers' career advancement. In such contexts, teachers commonly participate in what is termed as requested professional development 
by Evans (2011). Requested professional development is forced onto teachers. One example of the aforementioned context is Indonesia where top-down 'project-based' professional development programs are strongly prevalent (Sajidin, 2010). Most professional development activities in Indonesian schools are organized by the government, universities or private providers. Research in Indonesia shows that teachers have been involved in repeated and irrelevant trainings which have often resulted in a gap between what the teachers need and what the program offers (Evans, et al., 2009; Ashadi, 2010). Yuwono \& Harbon (2010) indicate that situational context such as low salary, time constraint and workload inhibits Indonesian teachers' professional development efforts as most teachers have a second job that hinders their ability to attend any professional development activities. In the Indonesian context, there is little, if any discussion of whether the emergence of the world wide web and online professional learning exists in teachers' repertoire for their professional development. This study seeks to answers two questions: (1) Do English teachers keep abreast of the changing nature of English teaching through online PL? If so, what are their online PL practices?; and (2) How does PD-related policy influence teachers' professional development dispositions for PL online? Answers to these two questions lead to our conceptualization of how teachers are learning when they are mostly governed by PD policy.

\section{METHOD}

As the study intended to examine teachers' professional development/online learning practices and dispositions, the study sought English teachers with active Continuing Professional Development (CPD) participation. To do this, the researchers approached two English teacher superintendents to recommend teachers who were active in their Continuing Professional Development (CPD) participation. Twelve teachers were recommended. Based on the following criteria four teacher participants (see Table 1) were selected: (1) having experiences in 4-5 predetermined CPD types (see full listing of types in Table 2), (2) having been teaching English for more than 10 years, (3) teaching at a senior/junior high school, and (4) holding professional teacher certificate. These criteria ensured that each participant was an experienced English teacher in the upper-schooling phase who was active in their professional development, and therefore aware of governing policy and more likely to be an expert seeking learning opportunities beyond the school site. At this point 
the four participants' engagement in online professional learning was unknown. The participants in this article are called by pseudonyms to preserve the confidentiality of their personal information.

Table 1. The Participants of the Study

\begin{tabular}{llll}
\hline \multicolumn{1}{c}{ Damien } & \multicolumn{1}{c}{ Serena } & \multicolumn{1}{c}{ Angelo } & \multicolumn{1}{c}{ Paulina } \\
\hline $\begin{array}{l}\text { 23 years teaching } \\
\text { experience }\end{array}$ & $\begin{array}{l}\text { 21 years teaching } \\
\text { experience }\end{array}$ & $\begin{array}{l}\text { 17 years teaching } \\
\text { experience }\end{array}$ & $\begin{array}{l}\text { 18 years teaching } \\
\text { experience }\end{array}$ \\
\hline $\begin{array}{l}\text { Senior high school } \\
\text { teacher }\end{array}$ & $\begin{array}{l}\text { Senior high school } \\
\text { teacher }\end{array}$ & $\begin{array}{l}\text { Senior high school } \\
\text { teacher }\end{array}$ & $\begin{array}{l}\text { Junior high school } \\
\text { teacher }\end{array}$ \\
\hline Having experiences & Having experiences & Having experiences & $\begin{array}{l}\text { Having experiences } \\
\text { in 5 CPD types }\end{array}$ \\
in 5 CPD types & in 5 CPD types & in 4 CPD types \\
\hline Holding & Holding & Holding & Holding \\
Professional & Professional & Professional & Professional \\
teacher certificate & teacher certificate & teacher certificate & teacher certificate \\
since 2010 & since 2010 & since 2013 & since 2011 \\
\hline
\end{tabular}

As mentioned previously, the participants' active CPD participation was determined by their experiences on 4-5 of the predetermined CPD types. These CPD types were the crystallization of various CPD types mentioned in the literature which has been used in a previous study (Utami, 2018). These CPD types were personally-initiated learning, publishing innovative works, attending organized professional development, upgrading qualification into more professional teacher and having a more advanced role (see Table 2 for details).

\section{Table 2. Five Predetermined CPD Types}

\begin{tabular}{|c|c|c|}
\hline No. & CPD Types & Description \\
\hline 1 & $\begin{array}{l}\text { Personally-initiated } \\
\text { learning (PIL) }\end{array}$ & $\begin{array}{l}\text { Any activity which is personally initiated: } \\
\text { personal reading, pursuing knowledge from } \\
\text { more expert peers/people, learning from } \\
\text { observing other teacher's teaching, developing } \\
\text { material for teaching, lesson planning, } \\
\text { developing syllabus, learning from self- } \\
\text { evaluation or others' evaluation, etc. }\end{array}$ \\
\hline 2 & $\begin{array}{l}\text { Attending organized } \\
\text { professional } \\
\text { development (OPD) }\end{array}$ & $\begin{array}{l}\text { Any activity organized by institutions or } \\
\text { organizations: attending workshops, seminars, } \\
\text { trainings, school professional development, } \\
\text { English Teacher Association (locally known as } \\
\text { MGMP) meeting, etc. }\end{array}$ \\
\hline
\end{tabular}




\begin{tabular}{lll}
\hline No. & CPD Types & Description \\
\hline 3 & $\begin{array}{l}\text { Publishing academic and } \\
\text { innovative works (PIW) }\end{array}$ & $\begin{array}{l}\text { Any activity related to sharing academic works: } \\
\text { publishing article, journal, research report, } \\
\text { course books, worksheet, module, text book, } \\
\text { inventing new discovery of efficient technology, } \\
\text { developing innovative learning or teaching } \\
\text { media, developing standard or test items used in } \\
\text { national or provincial level, etc. }\end{array}$ \\
& & $\begin{array}{l}\text { Holding professional teacher certificate (by } \\
\text { attending in-service teacher training or } \\
\text { submitting teacher portfolio) } \\
\text { Enrolling in master's or doctoral program }\end{array}$ \\
\hline 4 & Upgrading qualification \\
& into more professional \\
teacher (UQPT) & $\begin{array}{l}\text { Any activity which provides assistance to other } \\
\text { teachers: model teacher, teacher trainer, senior } \\
\text { teacher, material writer, mentor, instruction } \\
\text { designer. }\end{array}$ \\
\hline 5 & Having more advanced \\
roles (MAR) &
\end{tabular}

(Utami, 2018, p. 42)

Case study methodology was employed to represent each teacher's approach and reasoning for professional development. Merriam (2009) points out that "a case study is an intensive, holistic description and analysis of a single entity, phenomenon, or social unit" (p. 46). Each teacher was treated as one case. These cases illustrate the varying conceptualizations of professional development and the emerging use or non-use of the internet to facilitate professional learning. Case study allows the elaboration of the teacher's perspective responding to the contextual conditions (Yin, 2014), in this case, the professional development and professional learning activities.

Primary data were collected through in-depth individual interviews. Developmental interview was conducted with an interview guide which was not treated as a 'binding contract' (Glesne, 1999, p. 68) to enable the flexibility of the elaboration (Castillo-Montoya, 2016). Secondary data were collected by examining the participants' professional development portfolio and artefacts associated with their professional learning results. This serves as a triangulation data, which confirm the participants' CPD experiences, e.g., experience in attending training, workshops, or as a model teacher, which were reported in the interview.

Each participant was individually interviewed three times over six months lasting for approximately one hour each. The interviews were done in Indone- 
sian to reduce the anxiety and increase the elaboration of information as participants might have found it easier to express their thought in their native language. The interviews were done three times to support the reliability of the given information, in a way that previously asked questions were re-addressed and further discussed. The interview questions covered: teachers' approaches to learning; experiences of professional development and professional learning; and contextual learning affordance and barriers.

The interviews were digitally recorded and transcribed verbatim. The transcriptions were sent to the participants for validation to facilitate the accuracy of gathered information. To represent these teachers' professional development/learning dispositions and practices, a case study approach was adopted as a rich and descriptive narrative of the professional thoughts, events and understandings of the participants. This more holistic approach aligns with a qualitative paradigm which seeks to catch the wholeness of the individual (Cohen, Manion, \& Morrison, 2017). In this approach, direct phrases and sentences from the transcriptions were used to ensure that the voice of the teacher was validly represented which directed the descriptive prose provided by the researchers (Ball, 1994). The analytical process to construct each case followed the intentions of Stake's (2013) multiple case study employing both within-in case analysis and cross-case analysis to ensure a comparative analysis of the main themes. Each teacher interview was considered a case. The analytical process involved an inductive thematic procedure of examining, comparing, conceptualising and categorising the data in each case (Strauss \& Cobin, 1997). Several themes were described by codes assigned to selected segments of data. In the first round, each teacher case was thematically analysed and validated independently. Following this, the four teacher cases were analysed through constant comparison. This was done in order to ensure credibility of interpretation. Using the themes within each case, a descriptive prose was written that represented the individual dispositions and practices of each teacher as well as a comparisons of these with the other teacher cases. 


\section{FINDINGS AND DISCUSSION}

\section{Findings}

Damien: "I do web browsing when I need... I do attend seminar when I am required to."

Damien used to be a principal of a senior high school, curriculum national instructor and was currently the leader of English Teacher's association in his regency. He regularly attended school-based professional development and English teacher association meetings and spent approximately 3 hours per week on his personal reading related to English teaching.

Damien was aware of the policy which requires teachers to do classroom action research as their professional development. He said "I am now at the level of $4 B$, and I am required to do classroom action research." Damien admitted that his professional development participation was mostly to facilitate his research which was part of his requirements at this level. He stated that "I attended various workshops about research writing and followed the procedure but the thing is when the research finished, the evaluator always said there was something wrong in the methods, or layout so I had to repeat again... I don't understand... each evaluator has different perspectives about CAR report writing." The frustration on doing Classroom Action Research (CAR) and writing a report was very common among teachers, which is why Damien's idealism directs him to be a good model for other teachers. He thinks that it is his duty because he is a senior teacher. He said "I need to be a model at school as a senior teacher... because not many teachers want to do research." His professional development efforts were meant to encourage junior teachers to do something that others see as burdensome.

Besides attending required professional development and completing CAR, he also did some PL such as reading books, newspapers, research articles and English teaching materials he found on the internet which helped him understand and keep up to date with new curriculum. He said "I need to update myself with...because the curriculum is always changing. what is expected by the new curriculum, what is the expected class procedure so I can implement it in my class." In addition, his PL was also focused on teaching practices. He browsed the internet, searched for interesting classroom activity ideas, downloaded videos or material posted by bloggers which were related to his lessons. 
When he was asked about online collaboration, he said "I read blogs and I took interesting materials from it, but I don't contact people, I don't know them." His online activity is insubstantial. He described that he used the internet merely for obtaining new knowledge and resources. He also admitted that he did not think much of posting his own work, sharing or contributing, which was why he did not have his own blog and did not join certain online group or professional networks. He said "No, I don't have blog, when I share usually in the workshop that I facilitate or with my colleagues at school."

When he was asked the reasons for his web browsing and attending seminar, he said "I do web browsing when I need, for example when developing teaching materials. For attending seminar, the principal usually assigns certain teacher to go... so I do attend seminar when I am required to." Damien does both PD and online PL. For Damien formal professional development is something that is required to do but holds little developmental value and online PL is something that directly related to his needs.

Serena: "This online thing cannot be used to get credits for professional advancement, but I don't think it is a matter."

Serena was a secondary teacher who had never had another job other than being a teacher. She participated in various school directed professional development events. However, she spends 8 hours per week on her online selfdirected PL.

Serena believes in life-long learning. She actively attended professional development programs organized by educational organizations such as iEARN, British Council, and Microsoft. She valued these sessions as her participation inspired her to use new skills in her classroom. "Since I participated in iEARN, I developed new insight about teaching, ideas, creativity and networking. This was the first time I learn about teaching hybrid classroom with both elements of online and offline." She admitted that she was required to do professional development but she did not think it was the reason for her participation. "No, it is not for fulfilling the requirements, sometimes I don't even know how many credits I get for my activities. For me, I just want to learn something and try it in my class."

Serena sought out professional learning online where she was active reading research articles, web browsing, chatting and posting ideas through social networks. "Sometimes I just open my browser and type keywords or go to Fa- 
cebook groups just to know what's new or to contact people with interesting ideas." Her engagement in her personal learning networks led her to collaborate with teachers from other countries. She said "I had some collaborative teaching, for example the one I did through Machinto project with a teacher from Japan, we used teleconference room..." Apparently, her active engagement in her online networks brought impact to her classroom practices. When she was asked about the reason why she went online she said "I want to know what happens out there and see if I can use it in my class." Besides obtaining knowledge she also shared her knowledge. "I often did a webinar and talk about how to use Skype as a teaching tool."

She was aware that her PL activities were not counted for her career advancement. She did not seem to think much about the lack of credit for her online activities "This online thing cannot be used to get credits for upgrading my professional level, but I don't think it is a matter. What is important is to learn something that you need." For Serena both formal PD and PL are ways to learn something that she is interested in and motivated by that she could directly apply in her class and none was influenced by certain policy.

\section{Angelo: "If I attend seminar, I only get 0.1, it is very low compared to doing research, I got 4 credits."}

Angelo started his career as a civil servant teacher in 2000 . He was assigned to a local senior high school before he moved to a public vocational high school. Angelo was known for his outstanding achievement by the local English teachers. He participated actively in various research writing competitions and won many of them. He was selected to be a nominee for Outstanding Teacher at a national level.

Angelo attended various professional development activities. Some of them were related to classroom action research. When he was asked about the reason to do classroom action research he said. "because we are required to do classroom action research then teachers are inclined to do this kind of research." His answer reflects his concern on fulfilling professional requirement. He reported that his professional development was influenced by the consequences of his participation in relation to the credits to upgrade his career level "sometimes we need to see the usefulness of the activity, if I attend seminar, I only get 0.1 , it is very low compared to doing research, I got 4 credits." Clear- 
ly career advancement motivated and directed his professional development activity.

Angelo spent 1-2 hours per week on online PL. It was limited to downloading videos on YouTube and web-browsing activities to obtain authentic English materials. "I read blogs of native speaker to get materials, so it contains vocabulary or expressions used by native speaker." Angelo viewed using authentic English material is important and learning through browsing the internet provides him with what he needed.

He also became a member of an English teacher Facebook group but was not active. He rarely posted or contributed, "I only looked it up when I got notification and if it is interesting I open it, I'm not really active." When he was asked about his passive role in his online networks he said "I don't think I need to be active, it will make no different to my career." On the contrary, he loved sharing his research result in a seminar. He said "Sharing in the seminar means you get another point...". Although Angelo did both PD and PL, but he had different motivation underlying his participation. For Angelo, his formal professional development participation is intended to support his career advancement. Meanwhile, his self-chosen online PL is motivated by learning needs.

Paulina: "I think teachers should be knowledgeable and learn anything not only about their subject."

Paulina used to work as a hotel staff managing children care department and as a kindergarten teacher. She mentioned that these two previous jobs gave an influence on her current English teaching practices at secondary level especially in terms of planning a lesson and making learning fun for students.

When she was asked about the way she kept abreast with current English teaching practices she said that "I attend workshop like the one about how to learn English in a fun way.. I buy some books related to English teaching, I also read some articles in the internet...like to get ideas for teaching strategies." She had various ways of learning which includes participating in professional development and doing online PL. She also shared about her preference for professional development. "I love these workshops from private providers, they are more practical, more classroom problem based... something that closely related to answering problems in English teaching, the ones from government are usually theoretical such as socialization of new curriculum or new lesson 
plan structure." She preferred more practically focused professional development than theoretically focused.

Paulina's interest in learning was reflected through her active participation in various learning opportunities. She believed that teachers should possess broad knowledge even beyond their discipline. She said "I think teachers should be knowledgeable and learn anything not only about their subject. That's why I took Coursera courses about argumentative writing and science fiction." Her response shows that her reason for participating in these online courses was purely for learning and not specifically related to her classroom or the development of her pedagogy. She learned much from the feedback given by the professors of the courses. She said "I learned about professional dedication from these 2 online courses. The professors never looked down at my work. my English is not as good as native speakers...but they always encouraged me...It taught me how to treat student and motivate them." Although the two online courses were not about English teaching she learnt about professional disposition which provided her with new insight about motivating and respecting her students. She also explained her preference for online learning. She said "I also like finding some ideas to solve my problems through the internet... Internet helps me a lot in planning my lesson." Paulina believed that learning related to answering her problems was the most valuable.

In relation to her perception of organized professional development, she explained that "we are required to participate in professional development activities...there are some credits for that, but I never count how many credits for my participation." She did not think accumulating credits was her concern. She explained that she shared ideas and did collaborative research projects with her colleagues at school. Meanwhile, in the online context she was not much of a contributor. She said "I don't post anything more than personal status and information about local workshop or academic event ... I don't share my work in Facebook... When I have interesting materials or power point I share it with my colleagues at school because they have the same condition." Paulina views professional sharing to be more beneficial with those facing the same condition. For Paulina, both PD and online PL are useful as long as it is related to practical needs and answering classroom problems. 


\section{Discussion}

\section{Teachers' Learning through Formal PD and Online PL}

Referring to the first research question, in the findings the four teachers mentioned learning opportunities through PD which were directed by authoritative bodies and through online PL which was self-directed. They attended seminar, workshop or trainings organized by their schools or outside parties such as universities or the district educational department. These organized programs were commonly guided by an invited expert. The principals would assign particular teachers to participate in the programs. Very often the decision of assignment is given to those who needed the most in regard to upgrading career level as each teacher had to upgrade their career level regularly within 2-4 years. Thus, not all teachers have the opportunity. Lie (2007) also finds that not all Indonesian English teachers have the opportunity to participate in PD events. Similarly, Dayoub and Bashiruddin (2012) found that teachers in Syria and Pakistan are inclined to do self-directed learning due to lack of PD opportunities. Their participation in these professional development events is limited to receiving knowledge from the expert. These teachers mentioned the difference between government-organized programs and private provider-organized programs. The first was seen to be more theoretical and remote from solving everyday problems, while the second was seen to be more practical and relative to their classrooms; and thus, preferred by them. These findings are similar to teachers' perception in Cahyono's (2008) study from Indonesia who prefer PD activities with contents that can be implemented in their daily teaching.

Besides learning through attending PD events, these teachers also selfdirected their online PL by web-browsing, reading articles, downloading, modifying and using teaching materials they found in the internet. Their learning engagement via the internet was mostly for gaining knowledge with some sharing of their own knowledge or resources. They mentioned that they preferred to share with their colleagues at their school site as they face the same problems. Sharing online was not evident amongst the four teachers. This was indicated by the fact that these teachers did not have professional blogs nor did they consider sharing their works as important. Recent literature has discussed the importance of obtaining knowledge as well as giving/sharing knowledge in online professional learning engagement. As described by Trust (2012) online personal learning allows interpersonal connections, informal learning, collaboration, 
and exchanging knowledge and ideas. Online engagement with knowledge sharing activity encourages collective intelligent (Gee, 2004) through the contributions of ideas and curriculum materials by teachers. The absence of knowledge sharing culture in the teachers' online engagement need to be given attention. The knowledge sharing culture in online engagement needs to be encouraged.

This study advocates the tension between professional development participation and online PL engagement. Teachers found participating in professional development very often provided little learning with regard to what they needed. This is what led them to do self-directed online learning. They mentioned that the possibility of obtaining relevant knowledge was greater in their professional learning through browsing the internet or through self-chosen PD. Hood (2017) finds that teachers' learning engagement, either online or within their school context, is largely motivated by individual knowledge requirements and practice-based needs. Clearly, this study found that these teachers preferred to have a voice on what they want or needed to learn. For them, attending PD events, such as seminars or workshops, which were self-chosen were suitable to their needs and were as effective as online professional learning.

\section{The Influence of Policy on Professional Development Disposition}

Indonesian Law Number 14 of 2005 stipulates teacher commitment to improve their competence by actively participating in professional development activities (Depdiknas, 2005). To encourage teacher participation, government organizes various professional development projects. Sajidin (2010) termed this organized PD in Indonesia as 'centralized', i.e. 'teachers are gathered in a particular place and programs are developed and managed by the central government' (p.69). This definition of top-down or centralized professional development in Indonesia reflects traditional professional development practices (Stevenson, et al., 2016). Teachers are not involved in the decision making on what they perceive as important to improve their competence (McCray, 2016). Referring to the second research question, this study observed that teachers are required to participate in $\mathrm{PD}$ activities which are designed and determined by schools, government or authoritative bodies. As such the findings show that PD policies influence teachers' PD disposition. There are two different dispositions associated with fulfilling the policy demand: the compliant disposition and the indifferent disposition toward the policy. 
Compliant disposition was reflected by Damien and Angelo who focused on fulfilling the requirement. Their reasoning for participating in professional development is largely influenced by the standard of PD policy. The indifferent disposition was demonstrated by Serena and Paulina who participated in PD programs regardless of the policy demands. Their active participation in PD was not to fulfilling the policy demand. Hypothetically, with or without the existence of the policy demand, their action would be the same.

Teachers with compliant disposition try to demonstrate a 'standardised' professional teacher. Stillman \& Anderson (2015) theorized a relationship between teachers' identities and their participation in policy implementation. Teachers' identities direct them to act in relation to the policies. Moreover, teachers' professional development participation is governed by professional teacher standards (Su, Feng, \& Hsu, 2017). The problem with this act of appropriation is the tension between fulfilling the demand of the policy and learning what is useful for the teacher. This fulfilling policy demands action and is one motivating factor for professional development which is termed 'adaptation to external expectation' (Rzejak, Künsting, Lipowsky, Fischer, Dezhgahi, \& Reichardt, 2014). Teachers participate in PD as a requirement instead of directing their learning based on what they need. Su, Feng, and Hsu (2017) described this phenomenon as a gap between accountability and authenticity of professional development. By participating in PD programs teachers can provide accountable evidence of their PD participation but fail to gain authentic professional growth.

Teachers with indifferent disposition views organized PD as opportunities to learn. They seek learning opportunities instead of compliance. They choose what seminar and workshops they want to attend which suits their professional needs or interest. Their identities are not shaped by the standard but by the desire to learn. True learning desire has been viewed as another motivating factor for professional development possessed by teachers who have high professional enthusiasm (Utami, Saukah, Cahyono, \& Rachmajanti, 2017). Teachers with high professional enthusiasm are those who constantly hold positive perception on the impact of their professional development participation and are willing to demonstrate sustainable efforts to improve their professionalism (Utami, 2018). Teachers with indifferent disposition for compliance are active in any learning effort they see value in, including PL activities which are informal and selfdirected. Serena and Paulina found gaining knowledge and sharing knowledge 
as something that related to their development as professionals. Serena shared online while Paulina shared locally with her colleagues. In comparison, Angelo who has compliance disposition viewed sharing in his online network as not valuable and having no impact on his career development. For the two teachers with compliance disposition career orientation is considered as professional development motivation which shapes their professional development action (Rzejak, et al, 2014). It is defined as motivation with regard to increasing advancement opportunities, such as certificate acquisition or credit points for career promotion (Utami, 2018). Teachers with indifferent position such as Paulina and Serena do not see their learning action tied directly to career advancement; rather, they link it more to the attainment of professional growth and improvement. Rzejak, et al. (2014) termed this motivation as developmental orientation which is oriented to learning and development processes.

\section{CONCLUSIONS}

The study advocates that PD-related policy shapes teachers' professional development disposition for online PL. Teachers may have compliance disposition as they want to fulfil the policy demand. However, some teachers, possibly those with high professional enthusiasm, may also hold an indifferent disposition. These teachers' learning action is not motivated by fulfilling the policy demand but rather to join the developmental process of being professional teachers. There are clear implications of this study. Firstly, there needs to be a shift in compliancy and policy measures that allows teachers to make greater choices in PD activities which may include self-selected seminars and workshops. Tailoring professional development to specific needs and interests of teachers increases their motivation and the likelihood of transfer of new knowledge and practices to their classroom. Secondly, self-directed online PL opens up great opportunities for gaining new knowledge, keeping abreast of innovations and collaborating with like-minded colleagues from around the world. Online professional networks that are subject specific or pedagogical specific can provide further avenues to learn beyond the school context. Taking advantage of what the world has to offer can be as simple as browsing the internet. Teachers have a rich craft and understand their needs and the needs of their students. Encouraging teachers to learn and engage in curriculum based exploration on the internet in their own time and in any place is fortuitous, liberating and placing learning where it needs to be - in the hands of the teachers. 
The study has several limitations. Firstly, it was limited to interview data containing self-report of participants. Comparing self-report and actual practices gained through direct observation may provide more authentic description of the PD and PL tensions. However, in this study the participants were able to discuss their learning disposition and relate it with the policy demand. Secondly, the study's findings were derived from reports of four English teachers. This limited number of participants may not be adequate representation of a wide range of Indonesian English teachers. Hence, it is a pioneer study to provide a start for discussing teachers' disposition of PD and PL in the Indonesian context. Future research may include surveys of larger sample to provide more generalizable results and a baseline for qualitative interviews.

\section{REFERENCES}

Ambler, T. B. (2016). The day-to-day work of primary school teachers: A source of professional learning. Professional Development in Education, 42(2), 276-289.

Ashadi. (2010). School teachers' voice in professional development. In Selected papers in English language teaching (pp. 20-32). Jakarta: RELOIIEF.

Aubusson, P., Schuck, S., \& Burden, K. (2009). Mobile learning for teacher professional learning: Benefits, obstacles and issues. Research in Learning Technology, 17(3), 233-247.

Ball, S. J. (1994). Education reform: A critical and post-structural approach. Maidenhead: Open University Press.

Beltran, M., \& Peercy, M. M. (2014). Collaboration to teach English language learners: Opportunities for shared teacher learning, Teachers and Teaching : Theory and Practice 20(6), 721-737.

Brooks, C., \& Gibson, S. (2012). Professional learning in a digital age. Canadian Journal of Learning \& Technology, 38(2), 1-17.

Cahyono, B.Y. (2008). The continuous improvement learning programme for English language teacher: An Indonesian experience. In M. E. Vethamani \& M. K. Kabilan (Eds.), Practices and issues in English language teacher development (pp.61-78). Petaling Jaya, Malaysia: Sasbadi Sdn. Bhd. 
Campana, J. (2014). Learning for work and professional development: The significance of informal learning networks of digital media industry professionals. International Journal of Training Research, 12(3), 213-226.

Carpenter, J., \& Krutka, D. (2014). How and why educators use Twitter: A survey of the field. Journal of Research on Technology in Education, 46(4), 414-434.

Castillo-Montoya, M. (2016). Preparing for interview research: The interview protocol refinement framework. The Qualitative Report, 21(5), 811-831.

Cho, J. H. (2014). Teachers' perceptions of changes to teaching practice and the influence of professional development: Experienced EFL teachers in South Korea (Master's thesis, Victoria University of Wellington, Wellington, New Zealand). Retrieved from http://researcharchive.vuw. ac.nz/xmlui/handle/10063/3434

Cohen, L., Manion, L., \& Morrison, K. (2017). Research methods in education $\left(8^{\text {th }}\right.$ ed.). New York and London: Routledge.

Day, C., \& Sachs, J. (2004). International handbook on the continuing professional development of teachers. Maidenhead: Open University Press.

Dayoub, R., \& Bashiruddin, A. (2012). Exploring English-language teachers' professional development in developing countries: Cases from Syria and Pakistan. Professional Development in Education, 38(4), 589-611.

Depdiknas. 2005. Undang-Undang Nomor 14 Tahun 2005 Tentang Guru Dan Dosen [Law No. 14 Year 2005 on Teachers and Lecturers]. Jakarta: Departemen Pendidikan Nasional [Department of National Education].

Easton, L. B. (2008). From professional development to professional learning. Phi Delta Kappan, 89(10), 755-761.

Evans, L. (2011).The 'shape' of teacher professionalism in England: Professional standards, performance management, professional development and the changes proposed in the 2010 White Paper. British Educational Research Journal, 37(5), 851-870.

Evans, D., Tate, S., Navarro, R., \& Nicolls, M. (2009). Teacher education and professional development in Indonesia: A gap analysis. Retrieved from http://pdf.usaid.gov/pdf_docs/PNADS282.pdf 
Gee, J. (2004). Situated language and learning: A critique of traditional schooling. New York, NY: Routledge.

Glesne, C. (1999). Becoming qualitative researchers: An introduction (2nd ed.). New York: Longman.

Gore, J. (2014). Towards quality and equity: The case for quality teaching rounds. Research Conference 2014, 86-91. Retrieved from http://research.acer.edu.au/cgi/viewcontent.cgi?article=1233\&context=res earch_conference

Hood, N. (2017). Conceptualising online knowledge sharing: What teachers' perceptions can tell us. Technology, Pedagogy and Education, 26(5), 573585 .

Hsiao, Y. P., Brouns, F., Kester, L., \& Sloep, P. B. (2013). Cognitive load and knowledge sharing in Learning Networks. Interactive Learning Environments, 21(1), 89-100.

Kennedy, M. M. (2016). How does professional development improve teaching? Review of Educational Research, 20(10), 1-36.

Lie, A. (2007). Education policy and EFL curriculum in Indonesia: Between the commitment to competence and the quest for higher test scores. TEFLIN Journal 18(1), 1-14

Lieberman, A., \& Miller, L. (2014). Teachers as professionals: Evolving definitions of staff development. In K. L. Bauserman, S. Kragler, D. J. Quatroche \& L. Martin (Eds.), Handbook of professional development in education: Successful models and practices (pp. 3-21). New York, NY: Guilford Press.

Little, J. W. (1999). Organising schools for teacher learning. In L. DarlingHammond \& G. Sykes (Eds.), Teaching as the learning profession: Handbook of policy and practice (pp. 233-262). San Francisco, CA: Jossey Bass.

Loughran, J. (2010). What expert teachers do: Enhancing professional knowledge for classroom practice. London: Routledge.

McCray, C. (2016). Middle and high school teachers' perceptions of professional development (Doctoral dissertation, Walden University, 
Minneapolis, MN, USA) Retrieved from https://scholarworks.waldenu. $\mathrm{edu} / \mathrm{cgi} / \mathrm{view}$ content.cgi article $=4282 \&$ context $=$ dissertations

Merriam, S. B. (2009). Qualitative research: A guide to design and implementation. San Francisco, CA: Jossey-Bass.

Nilsson, P. (2012). From concept to school practice: Professional learning for sustainable change in the primary science classroom. In M. Kooy \& K. van Veen (Eds.), Teacher learning that matters: International perspectives (pp. 235-254). New York: Routledge.

O'Brien, J., \& Jones, K. (2014). Professional learning or professional development? Or continuing professional learning and development? Changing terminology, policy and practice. Professional Development in Education, 40(5), 683-687.

Opfer, V D., \& Pedder, D. (2011). The lost promise of teacher professional development in England. European Journal of Teacher Education, 34(1), 3-24.

Raphael, T., Vasquez, J., Fortune, A., Gavelek, J., \& Au, K. (2014). Sociocultural approaches to professional development: Supporting sustainable school change. In K. L. Bauserman, S. Kragler, D. J. Quatroche \& L. Martin (Eds.), Handbook of professional development in education: Successful models and practices (pp. 145-173.). New York: Guilford Publications.

Rzejak, D., Künsting, J., Lipowsky, F., Fischer, E., Dezhgahi, U., \& Reichardt, A. (2014). Facets of teachers' motivation for professional developmentResults of a factorial analysis. Journal for Educational Research Online, 6(1), 139-159.

Sajidin. (2010). Teacher professional development in language teaching: A shift of paradigm. Ragam Jurnal Pengembangan Humaniora, 10(2), 69-72

Stake, R. E. (2013). Multiple case study analysis. New York: Guilford Press.

Stevenson, M., Hedberg, J. G., O’Sullivan, K.-A., \& Howe, C. (2016). Leading learning: The role of school leaders in supporting continuous professional development. Professional Development in Education, 42(5), 818-835. 
Stillman, J., \& Anderson, L. (2015). From accommodation to appropriation: Teaching, identity, and authorship in a tightly coupled policy context. Teachers and Teaching: Theory and Practice, 21(6), 720-744.

Strauss, A., \& Corbin, J. M. (Eds.). (1997). Grounded theory in practice. Thousand Oaks: Sage.

Su, Y., Feng, L., \& Hsu, C.-H.. (2017). Accountability or authenticity? The alignment of professional development and teacher evaluation. Teachers and Teaching: Theory and Practice, 23(6), 717-728.

Trust, T. (2012). Professional learning networks designed for teacher learning. Journal of Digital Learning in Teacher Education, 28(4), 133e138.

Trust, T., Krutka, D. G., \& Carpenter, J. (2016). "Together we are better": Professional learning networks for teachers. Computers \& Education, 102, 15-34.

Utami, I. G. A. L. P., Saukah, A, Cahyono, B. Y., \& Rachmajanti, S. (2017). Levels of involvement in the English teachers' CPD (Continuous Professional Development): The degree of professional enthusiasm. The Journal of AsiaTEFL, 14(2), 336-345

Utami, I. G. A. L. P. (2018). The alignment of perceptions and practices of effective english teaching by English teachers with different CPD involvement levels (Doctoral dissertation, Universitas Negeri Malang, Malang, Indonesia).

Yin, R. K. (2014). Case study research: Design and methods (5th ed.). Thousand Oaks, CA: SAGE Publications

Ying, I. (2012). Exploring discursive practices of teacher learning in a crossinstitutional professional community in China. In M. Kooy \& K. van Veen (Eds.), Teacher learning that matters: International perspectives (pp. 176-194). New York: Routledge.

Yuwono, G. I., \& Harbon, L. (2010). English teacher professionalism and professional development: Some common issues in Indonesia. The Asian EFL Journal Quarterly: Special Issue on English Language Teacher Education and Development, 12(3), 145-163. 